
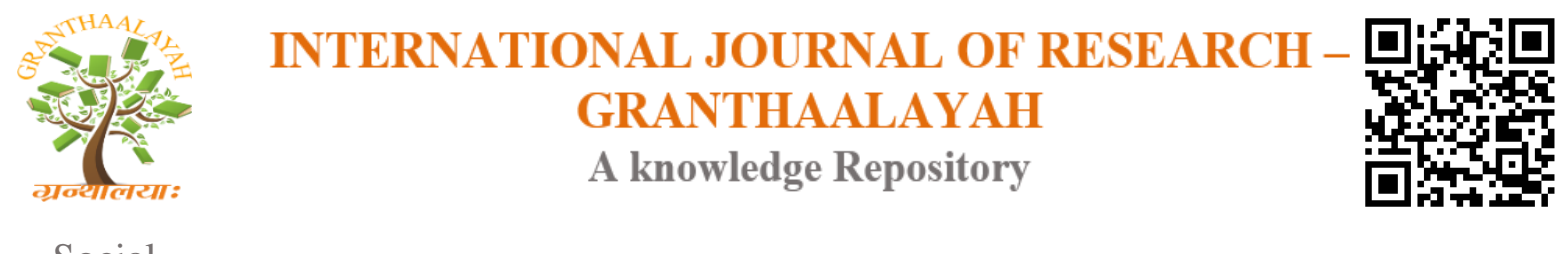

Social

\title{
RECONSTITUTIONALITY OF THE 1945 CONSTITUTION AFTER THE FOURTH AMENDMENT
}

\author{
Rusli Kustiaman Iskandar ${ }^{* 1}$, Efik Yusdiansyah ${ }^{1}$, Asyhar Hidayat ${ }^{1}$ \\ ${ }^{1}$ Faculty of Law, Universitas Islam Bandung, Indonesia
}

\begin{abstract}
The four amendments to the 1945 Constitution are imperatives of an imperfect human work. For Indonesia, the 1945 Constitution is the highest law (basic law) of all existing state norms and institutions. However, after careful scrutiny, it turns out that there are a number of provisions that weaken the constitutionality of the 1945 Constitution. The purpose of this article is to analyze the constitutionality of the 1945 Constitution after the fourth amendment. The method used is descriptive method and the method of constitutional comparison, with a qualitative juridical analysis approach to state administration. The conclusion of this article is that there are provisions that weaken the 1945 Constitution such as the 42 state affairs, government and state administration that submit further arrangements to the law. In addition, and especially if it is associated with the authority to change and develop itself, it becomes very dependent on the DPR. For this reason it is important to do constitutionality by making changes to the fifth and so on, beginning with compiling a grand design change that emphasizes legal and constitutional aspects rather than political aspects.
\end{abstract}

Keywords: Constitutionality; Grand Design; Change; Authority.

Cite This Article: Rusli Kustiaman Iskandar, Efik Yusdiansyah, and Asyhar Hidayat. (2019). "RECONSTITUTIONALITY OF THE 1945 CONSTITUTION AFTER THE FOURTH AMENDMENT." International Journal of Research - Granthaalayah, 7(9), 386-394. https://doi.org/10.29121/granthaalayah.v7.i9.2019.624.

\section{Introduction}

When for the first time the 1945 Constitution was promulgated on August 18, 1945, as the 1945 Constitution of the Proclamation [1], Chairman of the PPKI (Indonesian Independence Preparatory Committee) Soekarno made a statement: “.... and gentlemen all of them understand, that the current constitution is a temporary constitution. If I may use the words: this is the Basic Law of lightning. Later, if we have served in a more peaceful atmosphere, we will certainly reassemble the House of Representatives that can make the Constitution more complete and more perfect. Gentlemen ... that perhaps it may be said, this is revolutionary" [2]. 
A similar statement was previously made by two signatories to the United States Constitution of 1787, Madison and Moris [3]. Madison states: "I am not the number if there is any such, who thinks the Constitution lately adopted a faultless work ...". Furthermore, twenty years later Moris stated: "Nothing human can perfec. Surrounded by difficulties, we did the best we could; leaving it with those who should come after us to take counsel from experience, and exercise prudently the power of amendment, which we had provided, ... ".

Both Madison and Moris put forward for the US Constitution, and Sukarno for the Indonesian Constitution, at least containing three meanings related to the existence of the 1945 Constitution at that time. First, it shows consciously that as a human product, there is never a final, permanent, and perfect. Even if it is called perfect, then that perfection is very relative in nature. Second, the draft constitution was really made in a flash atmosphere, because it was only completed within 38 (thirty eight) days [2]. Third, for a Constitution stated by Wheare, that: "A Constitution is indeed the resultant of a parallelogram of political, economic, and social forces - when operating at the time of its adoption". Agreements reached by founding fathers, founding leaders, or founding peoples who are influenced by various external and internal factors, as a record of events (moment hospitalization) that occur when determined [4].

Therefore, it is very possible to have many shortcomings and weaknesses, have not been able to capture, let alone record events that will occur in the future, although conceptually and academically, legal drafter, especially draft constitution should be able to see the future. That is why, in every constitution or constitution, provisions or procedures for amending or developing themselves are always prepared or contained [5].

In the 1945 Constitution, both original and amended, provisions of this kind are found in Article 37. When formulated in 1945, the formulation of the provisions of Article 37, referred to as Soekarno as a chapter and locking article, rather than the Constitution. That is, through the provisions agreed in Article 37, the Constitution can still be changed by the quorum and the mechanism determined. Or amended not with ease or even simplified, but locked with special qualifications, namely the quorum and the verdict, declared by a majority vote determined, which in the 1945 Constitution is number $2 / 3$ of members of the MPR (People's Consultative Assembly) [6].

However, after the fourth amendment to the 1945 Constitution, the provisions of Article 37 also changed, with the mechanism and quorum as regulated in Article 37 of the original 1945 Constitution. But the mechanism and quorum needed to fulfill the planned amendment to the 1945 Constitution in the future, starting with the Fifth Amendment and so on, which must and must occur, has made the shift in the quorum heavier.

The weighting starts from the quorum for the proposal of change, the trial quorum of change, and the quorum to take the decision on the proposed change. However, the weight of the quorum seems to be more directed at protecting the interests of the political power that is in power, and is far from efforts to meet the needs and livelihoods of the people at large, especially in an effort to staatsidee or rechtsidee. 
Korum paragraph (1) for the proposed change must be approved by at least $1 / 3$ of the total number of MPR members. If a DPR member and a DPD member (Regional Representative Council) are considered as members of the MPR (Article 2 paragraph (1) of the 1945 Constitution), it turns out that membership to reach the quorum figure $1 / 3$ or $33 \%$, it can only be fulfilled by members of the DPR (House of Representatives). DPD members who are only 132 people out of 700 members of the MPR, which is equivalent to $18.85 \%$, will never be able to meet the quorum. This was confirmed by the provisions of the 1945 Constitution which stipulated that the total number of DPD members should not be more than $1 / 3$ DPR members.

Furthermore, related to the trial quorum discussing the proposed changes, which require a figure $2 / 3$ or equivalent to $67 \%$ of MPR members. In this quorum, again it will only be achieved by members of the DPR who have a significant figure, $81.15 \%$. DPD is increasingly powerless. As for the quorum for taking the decision on change, it is determined by an absolute majority vote, which is $1 / 2$ plus 1 of all MPR members, which is equal to $346+1$ or 347 votes. Even this number is only owned by members of the DPR.

From the above mathematical calculations, it is clear that changes to the provisions of Article 37 concerning the mechanisms, procedures, and procedures for changes to the 1945 Constitution in the future, become very dependent on the strength of a DPR institution on behalf of the MPR. The MPR, which is more of a joint season between DPR members and DPD members, does not reflect an equivalent institution as implementing the sovereignty of the people according to Article 1 paragraph (2). The MPR Korum can be reached by the DPR, with just one additional vote from the DPD that can be obtained easily. First, to fulfill the desire of power, the DPR can "kidnap" one DPD member to join the DPR, so that the MPR session quorum is fulfilled. In this quorum, the DPR can utilize the MPR to amend the 1945 Constitution which strengthens and protects its political interests (Iskandar, 2015). Or, secondly, the DPR is silent as it is today, because there is a possible reason that the provisions of the existing 1945 Constitution are strong enough to preserve and protect the interests of the DPR now and in the future.

The silent principle of being a DPR now is similar to the political decision of the MPR in the New Order era, which did not intend to make changes to the 1945 Constitution, but would implement it purely and consistently, even though this political decision was contrary to natural nature. According to Manan [7], there are three facts that are opposed, namely: First, the 1945 Constitution itself provides opportunities for change. Second, both sociologically and naturally, a legal provision will experience obsolescence (overordered). Prohibiting or complicating changes in such a way, will cause the Constitution to be materially dead (the dead constitution) as opposed to the obligation to always maintain and maintain that the Constitution or the constitution is still alive (living constitution). Third, to further realize staatsidee, especially the notion of popular sovereignty and democracy. For example, the presidential election by the MPR has a democratic nature, because the MPR is the embodiment body or representation of all the people of Indonesia. But directly elected by the people, far more democratic than indirectly chosen by the MPR. Therefore, if the current DPR members really have a high sense of constitution, such provisions should be immediately proposed to be amended, because maintaining them is tantamount to worsening the image of the DPR and the MPR itself, in addition to the image of the 1945 Constitution as the highest law, it becomes slumped down. 
In the Indonesian context, the meaning of change which has become a political agreement, is to change the material contained in the Constitution, and not to change its Preamble and its contents, constitutes the "fundamental principle of the state" as the basic principle of state spirituality [8]. In it as repeatedly explained above, includes staatsidee and rechtsidee, namely: first, the ideals of protecting the whole nation and all bloodshed; second, the ideals of popular sovereignty; third, the ideals of the rule of law; fourth, the ideals of constitutional states; and fifth, the ideals of public welfare. That is, if changes to the 1945 Constitution must be made, then the changes must be in order to realize the fourth or fifth of these ideals.

Meanwhile, the fourth result of changes made between 1999 and year in 2002, it turned out to be very far from trying to realize the fourth or fifth of the above ideals. The description related to the provisions on the procedure for amending the 1945 Constitution in Article 37 only tends to guarantee the political interests of the DPR more than the interests of the people. This means that no change is found that is specifically oriented to efforts to realize the lofty ideals of the Preamble of the 1945 Constitution.

From the description above, it cannot be denied that the results of the First Amendment to the Fourth Amendment of the 1945 Constitution, which were carried out in 1999 to 2002, have led to the reduction of the constitutional characteristics of the 1945 Constitution as the highest law in reference to legislation, and as a limitation of state power. However, the hope of the 1945 Constitution residing as the highest law still exists, through the existence of the Constitutional Court as the guardian of constitution, the guardian of human rights, and the guardian of democracy and people sovereignty. But all of that, it is not enough to guarantee the constitutionality of the 1945 Constitution. Hopes that are too dependent on constitutional judges, must also be accompanied by certain restrictions. A number of cases that are wrapped around constitutional judges, must be made a lesson, that hanging hopes on one's integrity, is apparently not entirely true and correct. Therefore, in addition to hanging hopes on one's integrity, it must also be accompanied by the strength of constitutional provisions that are able to protect themselves (the power of constitution to protect itself). This power will stimulate the guardian of the constitution (MK) in protecting the elevation of the 1945 Constitution. To achieve this position, the reconstitutionality of the 1945 Constitution will only be achieved by changing it for the fifth time and so on, framed by a grand-design that emphasizes legal principles, while reducing even eliminate the intensity of political interests from various political forces that exist.

\section{Method}

This paper was prepared using descriptive and constitutional comparison methods, with a qualitative juridical analysis approach to state administration. That is, this article is intended to describe the state of the 1945 Constitution after the fourth amendment, which apparently does not fully reflect the constitution, especially in terms of position and function. The provisions contained therein lead to irregularities in position and function. The use of the method of constitutional comparison, because it has become the character of legal science, especially the science of state administration law which is very "requires" methods of comparison as an effort "in gaining a better understanding of one's own national law and in the work of improving it" (improving and develop understanding and improvise knowledge of one's own law) [9]. In applying this comparison method, the author does not specifically choose a particular country's constitution, but rather the 
essence of the existence of a country's constitution. Since this article is about the 1945 Constitution, comparisons will be emphasized more on the concepts of the constitution that exist in a constitution of another country, including comparing with the constitutions that have been in force in Indonesia in the past.

\section{Results and Discussions}

\subsection{Position and Function of the Constitution}

Doctrinally, the position of the Constitution or the constitution anywhere in the world is always placed as the highest legal norm in the country. It means to demand that every other legal principle outside the Constitution, its contents must not conflict with the Constitution, both normatively and in constitutional doctrine, especially with the soul of "rechtsidee" or "staatsidee" in Indonesia called Pancasila.

During this time there is a kind of misunderstanding of the legal principle of a statutory regulation. As if what is meant is only a matter of a norm that does not conflict with the norm (aple to aple). Though it is more important to note, that every norm created, must always be in line and must not conflict with the principle or "rechtsidee" and "staatsidee" adopted.

For this reason, although there are many laws that so far, especially after the reforms that have been advocated by the "community" to the Constitutional Court (MK), can be ascertained because the norms contained in the Act, are not solely for reasons that conflict normatively, but most likely because they are not in line even contrary to the philosophical basis of "rechtsidee" or "principle" and "staatsidee" contained in the 1945 Constitution. At least, before any conflict was found and during the process of testing a law that contradicted the 1945 Constitution, it remained valid as a valid and binding regulation.

Under these circumstances, the 1945 Constitution, experienced a degree of distortion and loss of position as the highest principle in the country. When this situation approaches it, it is difficult to expect the 1945 Constitution to be used as a guideline or role model in carrying out Indonesian state administration well. That is because, as best as possible the provisions of the Constitution are owned, it does not guarantee the birth of goodness in its application. Especially if the existing provisions actually provide multiple interpretations, or even the certainty of the provisions does not benefit himself. Add to this the poor state actors by fostering an ethics of state administration in order to cover up the shortcomings and weaknesses of the existing provisions.

Regarding functions, the entire constitution in general or the Constitution in particular, including the 1945 Constitution, is a limitation of state power in Indonesia. Or form any state power, which is completely limited (limited of powers, or limited government). That limitation, including through the regulation and determination of the duties, powers, or authority of each power in the country, one of which can be in the form of separation or distribution of powers.

After the fourth amendment, it turns out that the 1945 Constitution still contains a number of provisions which do not fully guarantee limited or limited state power. There are even provisions that "quietly" strengthen a state institution while weakening other state institutions. This is evident, 
with 42 functions, including state, government and state administration matters, which are cumulatively handed over to the law. That is, it involves the role and political interests of the DPR. This situation shows the semantic function of the 1945 Constitution, which is in tandem with the "corrupt" nature of power [10]. The principle does not guarantee the distribution of power wisely and fairly, even becoming an obstacle to the establishment of the principles of constitutionality that encourage the growth of political ethics and state administration, even though it is highly dependent on the integrity of individuals individually [11].

\subsection{History of the Indonesian Constitution and the 1945 Constitution}

To achieve a good understanding, this sub-section will look briefly about the Indonesian Constitution and the 1945 Constitution. In reality and practice, Indonesia is one of the countries rich in the Constitution, in addition to France. At least, within 5 years of independence, they already have three constitutions, namely in addition to the 1945 constitution, there is the 1950 Provisional Constitution, and the 1949 Republic of Indonesia Constitution (RIS).

Moreover, the 1945 Constitution, which in Indonesian political and constitutional history has a long and winding history. The 1945 Constitution applies in various periods and their implementation. First, it is called the 1945 Proclamation. That is because his birth was related to and directly connected with the proclamation, or as a direct result of the proclamation. Secondly, it acts as the Constitution of the Republic of Indonesia Yogyakarta, when Indonesia changes to become a union state, under the RIS Constitution of 1949. In fact, while acting as the Constitution of the Republic of Indonesia, from this 1945 Constitution many gave birth to various monumental state administration events.

But since returning to the form of a unitary state by using the 1950 Constitution, the existence of the 1945 Constitution has disappeared in the Indonesian political arena and state administration. The 1945 Constitution which was declared as a formal amendment to K.RIS 1949 by eliminating the elements of federalism and replaced by the principles of unity, was accepted as a unitary constitution as determined in the provisions of Article 190 paragraph (1). The acceptance of the 1950 Constitution was based on the belief that all the principles of the unitary state were in accordance with the ideals of the August 17, 1945 proclamation contained in the 1945 Constitution, particularly Article 27, Article 29, and Article 33, also contained explicitly in the 1950 Constitution. in Article 13 paragraph (1); Article 29 contained in Article 43; and Article 33 is contained in Article 38. Based on these conditions, the distance of thinking of this nation is further and different from the 1945 Constitution. It is as if the 1945 Constitution has been incarnated "reincarnation" into the 1950 Constitution.

However, due to political changes due to the implementation of the first elections in 1955, which resulted in the Constituent Assembly as a change body to the Constitution, the distance of thought to the 1945 Constitution, it was unexpectedly very close and short. The temporary nature of the 1950 Constitution must be immediately terminated, replaced with a permanent Constitution, as ordered by Article 134, which reads: "The Constitution (Constitutional Court Session) together with the Government, as soon as possible establishes the Constitution of the Republic of Indonesia which will be replace the Provisional Constitution ". 
The constituents produced from the December 15, 1955 General Election immediately set the agenda to establish a Constitution to replace the 1950 Constitution. The body convened in Bandung for almost three and a half years (1956-1959). Conceptually, in fact the Constituent Assembly has succeeded in formulating a new constitution intended as a permanent constitution, only collided with the basic problems of the state as "rechtsidee" and "staatsidee", which always stalemate, especially addressing the President's mandate at the Constituent Assembly on 22 April 1959, with the word -word: "Let us return to the 1945 Constitution". How to return to the 1945 Constitution, the President invited the Constituent Assembly to determine.

Instead of determining how to return to the 1945 Constitution, there was an escalating ideological conflict. Regarding the basic choice of the state, in the Constituent Assembly at that time, it was divided into three large and influential groups. The group that wants the basis of the Pancasila state, the group that wants the basis of an Islamic state, and the group that wants the basis of a socio-economic state supported by the communist-leaning Labor and Acoma parties. These three groups were very influential in the hearing of constituents, which then caused the Constituent Assembly to really "split up", even to be declared "failed", which was marked by a "strike" siding [12].

For the President, the strike was a threat to the integrity of the nation and the state, as well as ending it by issuing a Presidential Decree on July 5, 1959, two of which mainly stated: "dissolve the constituents", and declare "the 1945 Constitution and the 1950 Constitution" . Both contents of this decree are based on five considerations, one of which is the fifth consideration which states: "that we believe that the Jakarta Charter dated June 22, 1945 animates the 1945 Constitution and is a series of unity with the constitution".

This decree caused the 1945 Constitution to return to the Indonesian political and state administration for the second time. But in this second period, the 1945 Constitution has not even been implemented properly. In practice, both in the old order era (ORLA) July 5, 1959 s.d. March 11, 1966, as well as the new order era (ORBA) March 11, 1966 to May 21, 1998, including in the reform era May 21, 1998 until now, has a movement that is not much different. In the reform era, there were two phases, namely: the first phase, May 21, 1998 s.d. October 19, 1999; and the second phase, 19 October 1999 (First Amendment) 10 August 2002 (Fourth Amendment) to the present. After these four changes, Bagir Manan [13] called the New 1945 Constitution.

\section{Constitutionality of the 1945 Constitution Post Amendment}

Indeed, the only way to achieve the reconstitutionality of the 1945 Constitution is through change. In the science of constitutional law, the mechanism of change can be adopted with two possibilities, namely: formal changes (formal amendments) and informal changes (unformal amandements). Between both formal and informal ways, by Carr [14] formal change is something that is not very important. The Constitution can be developed through non-formal ways that are far more effective and effective. The non-formal way can be done through the interpretation or convention of state administration.

However, in the context of the current constitutional reconciliation of the 1945 Constitution, what is needed is change in formal ways, or it cannot be done through convention or legal interpretation. Must be done by actually changing the formulation or sound of the provisions of the 1945 
Constitution. Formal changes are still needed to maintain the things that are very important and fundamental in the country, and so that the changes are done carefully, not "haphazardly".

Changes that must be made now, really touches on fundamentals, namely the constitutionality of the re-constitution of 1945. Articles that indicate they are not regulating and limiting power, must be changed. The position and power of the DPD, for example, is important to be aligned with the DPR, so there is a balance between the two state institutions, as well as a later balance between the legislature (DPR) and the executive (President).

As mentioned earlier in this paper, presenting the DPD in the state institutional structure is intended to build a two-chamber representative system in the MPR. In a two-room system, the principle of checks and balances will run and function properly, so that in the formation of the Act there will be a synergy between the interests of all the people (DPR) with the interests of the region and the people of the provincial area (DPD). In the current position of the DPR and DPD, those hopes will not occur, because the more dominant and more powerful person is the DPR. Furthermore, to make the Constitution as the basic law and the highest law in the country, changes must be made in order to realize the staatsidee and rechtsidee that have been written and agreed upon by the founding leaders of Indonesia in the Preamble to the 1945 Constitution.

There are two important designs chosen in carrying out the reconstitutionality of the 1945 Constitution, namely: First, reducing if necessary removing the provisions of the 1945 Constitution which gives too much space to the DPR as the holder of legislative power to form a law. There are 42 material found in the 1945 Constitution which further implementation is in or with the organic law. This number must be reduced, at least matters relating to state power, must be completed in the 1945 Constitution. No longer submitted to the legislators. This is to reduce the intervention of the interests of lawmakers in regulating the structure and power of state institutions. Meanwhile, to further exercise the power of government and state administration, it should be regulated further in or by law involving the interests of the people represented by the DPR. Second, change must really be directed at the second, third, or fourth concretization of the basic ideas of the state above. This will be mutatis mutandis with the achievement of the idea of reconstitutionality of the 1945 Constitution being the highest law in the state. Of course, in it, it also involves changes in the technical matters of legislation must be standardized in the provisions of the Constitution. That is, change must be a grand design that is comprehensive, and free from the interests and political intrigue of various parties who seek power, deify the position and power. Therefore, in other writings, the writer states the fifth amendment, the latest amendment by the MPR, but it is full of various wise and virtuous attitudes, statesmanship, all of which are oriented towards the interests of the people, nation, and state. If the MPR, which today is dominated by the DPR, is unable to act as statesmen, then there is only one option, namely to propose to the President, in order to save the 1945 Constitution from the deterioration of position, nature, and function, to form a design team for amending the Constitution 1945, the results of which must be determined constitutionally by the MPR, vide Article 3 paragraph (1) of the 1945 Constitution. But the determination by the MPR, is not submitted in the form of "blanks", but rather stipulates something that is final from the body or team amending the 1945 Constitution., the team formed by the President, are those constitutional experts who have the spirit of statesmanship, free from political interests and power, except for the interests of the people, nation and beloved country of the Republic of Indonesia. 


\section{Conclusions}

The 1945 Constitution has lost its position and function as the highest law in the state, and a limitation of state power. There are various provisions in it that do not reflect constitutional rules, such as not limiting state power, not sharing power fairly and proportionally. This was proven by the existence of 42 matters of state, government and state administration, which submitted further arrangements to the law. It means that it involves the political interests of the DPR, which are not oriented towards achieving the country's goals, welfare. DPR gets the position as the highest state institution, which is strengthened by the provisions of Article 22C paragraph (2) and Article 22D. While based on the provisions of Article 1 paragraph (2), all state institutions should have equal status. The DPR is the most decisive state institution when the MPR will make changes to the 1945 Constitution in the future. That is because the composition of DPR membership (560) in the MPR (696) is equivalent to $80.46 \%$. While DPD (136) is equivalent to $19.54 \%$. This means that only the DPR can fulfill all the quorum needed to implement the provisions of Article 37, amending the 1945 Constitution.

\section{References}

[1] Assaat, Hukum Tata Negara Republik Indonesia dalam Masa Peralihan, Djilid 1, Bulan Bintang, Djakarta, 1951.

[2] Moh. Yamin, Naskah Persiapan UUD 1945, Jilid Pertama, Cetakan kedua, Siguntang, Jakarta, 1971.

[3] Bagir Manan, DPR, DPD, dan MPR dalam UUD 1945 Baru, FH-UII Press, Cet.1, Yogyakarta, 2003.

[4] Moh. Mahfud MD., Perdebatan Hukum Tata Negara Pasca Amandemen Konstitusi, LP3ES, Jakarta, 2007.

[5] Harun Al-Rasyid, Naskah UUD 1945 Sesudah Empat Kali Diubah Oleh MPR, Penerbit Universitas Indonesia, Revisi Cetakan Pertama, Jakarta, 2003.

[6] Sri Soemantri, Prosedur dan Sistem Perubahan Konstitusi Dalam Batang Tubuh UUD 1945 (Sebelum dan Sesudah Perubahan UUD 1945), Edisi Kedua, Cetakan Pertama, Alumni, Bandung, 2006.

[7] Bagir Manan, Konvensi Ketatanegaraan, FH UII Press, Cetakan Pertama, Yogyakarta, 2006.

[8] Notonagoro, Pemboekaan Oendang-Oendang Dasar 1945 (Pokok Kaidah Fundamentil Negara Indonesia), UGM, Yogyakarta, 1957.

[9] David, Rene, Major Legal System in the World Today, Stevens \& Sons, London, 1985.

[10] Abu Daud Busroh dan Abubakar Burso, Asas-Asas Hukum Tata Negara, Ghalia Indonesia, Cetakan Pertama, Jakarta, 1983.

[11] Dicey, A.V., An Introduction to the Study of the Law of the Constitutions, $10^{\text {th }}$.ed., EL\&S and MacMillan, London, 1967 (reprinted).

[12] Simorangkir, JCT., Penetapan UUD Dilihat dari Segi Ilmu Hukum Tata Negara Indonesia, Gunung Agung, Jakarta, 1984.

[13] Bagir Manan, Teori dan Politik Konstitusi, FH-UII Press, Cetakan Pertama, Yogyakarta, 2003.

[14] Carr, Robert K., Marver H. Bernstein, Donal H. Morrison, Jospeh E. McLean, American Democracy in Theory and Practice: National, State, and Local Government, Holt, Rinehart and Winston, New York, 1961.

*Corresponding author.

E-mail address: rusliiskandar.unisba@ gmail.com 